Article

\title{
Suppressing Heavy Metal Leaching through Ball Milling of Fly Ash
}

\author{
Zhiliang Chen, Shengyong Lu*, Qiongjing Mao, Alfons Buekens, Wei Chang, Xu Wang and \\ Jianhua Yan
}

State Key Laboratory for Clean Energy Utilisation, Institute for Thermal Power Engineering, Zhejiang University, Hangzhou 310027, China; czl_andy@163.com (Z.C.); 21027080@zju.edu.cn (Q.M.); abuekens@vub.ac.be (A.B.); changwei0901@126.com (W.C.); wangxu@zju.edu.cn (X.W.); yanjh@zju.edu.cn (J.Y.)

* Correspondence: lushy@zju.edu.cn; Tel.: +86-139-5713-7049

Academic Editor: Ola Eriksson

Received: 4 May 2016; Accepted: 30 June 2016; Published: 8 July 2016

\begin{abstract}
Ball milling is investigated as a method of reducing the leaching concentration (often termed stablilization) of heavy metals in municipal solid waste incineration (MSWI) fly ash. Three heavy metals $(\mathrm{Cu}, \mathrm{Cr}, \mathrm{Pb})$ loose much of their solubility in leachate by treating fly ash in a planetary ball mill, in which collisions between balls and fly ash drive various physical processes, as well as chemical reactions. The efficiency of stabilization is evaluated by analysing heavy metals in the leachable fraction from treated fly ash. Ball milling reduces the leaching concentration of $\mathrm{Cu}, \mathrm{Cr}$, and $\mathrm{Pb}$, and water washing effectively promotes stabilization efficiency by removing soluble salts. Size distribution and morphology of particles were analysed by laser particle diameter analysis and scanning electron microscopy. X-ray diffraction analysis reveals significant reduction of the crystallinity of fly ash by milling. Fly ash particles can be activated through this ball milling, leading to a significant decrease in particle size, a rise in its BET-surface, and turning basic crystals therein into amorphous structures. The dissolution rate of acid buffering materials present in activated particles is enhanced, resulting in a rising $\mathrm{pH}$ value of the leachate, reducing the leaching out of some heavy metals.
\end{abstract}

Keywords: ball milling; MSWI fly ash; heavy metals; stabilization; water washing

\section{Introduction}

Municipal solid waste incineration (MSWI) fly ash has been classified as hazardous waste because of the presence of contaminants such as heavy metals and dioxins. Currently, treatment of fly ash has become an urgent environmental issue in China. The most common method of fly ash elimination is landfill disposal, after cement-based solidification of heavy metals. However, cement addition does not degrade polychlorinated dibenzo-p-dioxins (PCDD) and -furans (PCDF). Besides, the volume of fly ash significantly increases after treatment, which rapidly reduces existing landfill capacity. New landfill sites are often opposed to by local residents. So it is important to develop novel methods to render MSWI fly ash harmless and-if possible—recyclable.

Mechanochemical (MC) treatment changes the structure and physicochemical properties of fly ash through different mechanical forces such as compression, collision, friction and shear, accompanied by slight heating (ca. $50^{\circ} \mathrm{C}$ ). MC treatment has been successfully used in the destruction of persistent organic pollutants (POPs) such as hexabromobenzene [1], chlorophenol [2,3], perfluorooctane sulfonates [4] (PFOS), polychlorinated biphenyls [5,6] (PCBs) and also of polymers such as polyvinyl chloride [7] (PVC). Besides such chlorinated, brominated and fluorinated organic compounds, also dioxins and furans [8,9] in MSWI fly ash can be almost completely degraded with MC treatment. Mitoma et al. [10] milled fly ash together with calcium-based reagents in a planetary ball mill and 
attained a degradation of near $100 \%$. Yan et al. [11] milled fly ash without any additive, yet achieved good degradation efficiency of PCDD/Fs. The result indicates that both metal oxides and quartz contained in fly ash may play the role of abrasive or reductive reagents. Fly ash contains metal oxides such as $\mathrm{CaO}, \mathrm{Al}_{2} \mathrm{O}_{3}, \mathrm{Fe}_{2} \mathrm{O}_{3}, \mathrm{MgO}$ and quartz.

Except for the degradation of POPs, MC can also be adopted to induce reaction between mineral materials or metals [12,13], and to modify the mineral materials by mechanical activation [14-17]. For instance, El-Eskandarany et al. [18] synthesized alloy powders of $\mathrm{Nb}_{50} \mathrm{Zr}_{10} \mathrm{Al}_{10} \mathrm{Ni}_{10} \mathrm{Cu}_{20}$ by milling elemental $\mathrm{Nb}, \mathrm{Zr}, \mathrm{Al}, \mathrm{Ni}$, and $\mathrm{Cu}$ powders. In addition, they also reduced the haematite with magnesium to metallic Fe by MC treatment [13]. Hamzaoui et al. [17,19] modified fly ash using MC treatment, promoting the mechanical performance of substituted cement paste, moreover transforming proclay kaolinite to amorphous kaolinite which is similar to metakaolinite.

Recently, MC treatment has been introduced to stabilise heavy metals in both contaminated soil and fly ash. For example, Montinaro et al. [20] used dry ball milling to remedy sandy, bentonitic and kaolinitic soils, contaminated by heavy metals $\mathrm{Cd}^{2+}, \mathrm{Pb}^{2+}$, and $\mathrm{Zn}^{2+}$, reducing the leachable fraction of heavy metals to levels below the USEPA regulatory thresholds.

So far only lead was effectively solidified by MC treatment. Nomura et al. [21,22] stabilised Pb in fly ash by milling it with $\mathrm{CaO}$ in a dry planetary ball mill; the concentration of $\mathrm{Pb}$ in leachate was reduced by $93 \%$. Li et al. [23,24] stabilised lead in fly ash by wet ball milling. Pb elution was reduced by about $96 \%$ compared to untreated fly ash: $\mathrm{Pb}$ was sealed inside the milled fly ash during the fragmentation and subsequent agglomeration of particles. Stabilisation may be explained by the creation of fresh surfaces during ball milling, trailed by the formation of insoluble compounds, as caused by the high surface energy of freshly ground particles. Heavy metals are also possibly entrapped into aggregates: the crystalline structure acts like a net; this net shows some defects in which heavy metals are entrapped [20].

Dioxins and heavy metals are the two chief contaminants in MSWI fly ash, yet MC treatment is a simple, low cost, ecologically safe, and effective method for detoxification of MSWI fly ash, i.e., both degradation of dioxins and stabilization of heavy metals. MC treatment requires no heating, so that no hazardous gases are produced or sophisticated Air Pollution Control Devices needed. Furthermore, local residents could easily accept a fly ash MC treatment plant. However, the stabilization mechanism of heavy metals in MSWI fly ash was studied only recently. In the present work, we analyse the efficiency of MC treatment of heavy metals $(\mathrm{Cu}, \mathrm{Cr}, \mathrm{Pb}, \mathrm{Cd}, \mathrm{Ni}$, and $\mathrm{Zn})$ in MSWI fly ash without additives and also investigate the mechanism of heavy metals stabilization.

\section{Materials and Methods}

\subsection{Sampling and Pretreatment}

Fly ash was taken from the bag filter of a circulating fluidized bed (CFB) MSWI plant located in Hangzhou, Zhejiang Province, China. The incinerator has a capacity of 800 tons per day and operates at approximately $850^{\circ} \mathrm{C}-950{ }^{\circ} \mathrm{C}$. The flue gas treatment involves spray neutralisation with a hydrated lime suspension and activated carbon injection. Part of the fly ash was washed with water to remove soluble salts, such as sodium chloride, potassium chloride and calcium chloride. A two-stage process with a water/solids ratio of 5 was adopted. At each stage, the solution was vibrated for $30 \mathrm{~min}$ on a horizontal water bath oscillator at $25^{\circ} \mathrm{C}$. Both the fly ash (FA) and the washed fly ash (WFA) were placed in an oven at $105^{\circ} \mathrm{C}$ onto plates for $24 \mathrm{~h}$, to be dried.

\subsection{Ball Milling Experiments}

A new type of planetary ball mill with a commercial name of all-dimensional planetary ball mill (QXQM-2, Changsha Tencan Powder Technology Co., Ltd., Changsha, Hunan, China) was used for the MC treatment (Figure 1). Compared with the planetary ball mill, this unit adds a dimension of rotation. The whole object consisting of disk and all pots slowly rotates (1 rpm) around a main 
spindle to avoid sedimentation of materials caused by gravity, making powders to be ground more completely. The milling pots, with volume of $500 \mathrm{~mL}$, and balls with either $8(2.1 \mathrm{~g})$ or $12(7.1 \mathrm{~g}) \mathrm{mm}$ diameter are made of stainless steel. About $40 \mathrm{~g}$ fly ash and $40 \mathrm{~g}$ WFA were charged into each pot, together with 10 big balls and 43 small balls under atmospheric conditions, with a ball to powder ratio of $4 \mathrm{wt}$./wt. The mill was operated for $20 \mathrm{~h}$, with a 30-min driving belt cooling interval every $30 \mathrm{~min}$ [25]. The rotation speed of the disk and pots were respectively set as $300 \mathrm{rpm}$ and $600 \mathrm{rpm}$, and the rotational direction changed automatically every $30 \mathrm{~min}$. After MC treatment, both milled fly ash (MFA) and washed and milled WFA (MWFA) were collected for heavy metals leaching tests and analysis.

Stabilization efficiency was calculated based on the following formula:

$$
\frac{H M_{\text {original }}-H M_{t}}{H M_{\text {original }}} \times 100 \%
$$

where $H M_{\text {original }}$-the leaching concentration of heavy metals before milling and $H M_{t}$ 一the leaching concentration of heavy metals after a period of milling.

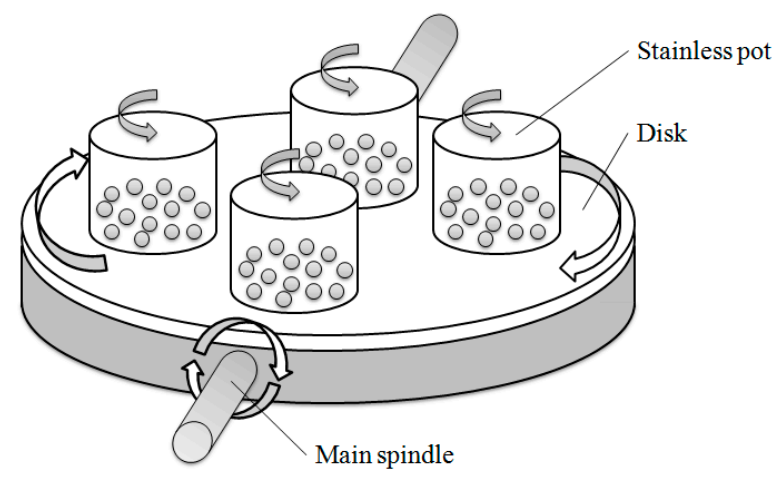

Figure 1. Schematic representation of an all-dimensional planetary ball mill.

\subsection{Analytical Methods}

The leaching of heavy metals from the MC treatment residue was investigated by means of a test based on method HJ/T300-2007 from the Ministry of Environmental Protection of the People's Republic of China and followed by the determination of the heavy metal concentrations by coupled plasma atomic emission spectrometry (ICP-AES, iCAP6300). The HJ/T300-2007 method is a leaching test similar to TCLP (USEPA method 1311). Table 1 shows the results from a comparison of these two methods. In the $\mathrm{pH}$ related leaching test, different volumes of glacial acetic acid (including 0 , $1,3,6,9,12,13,14,15,16,17,22,27$ and $34 \mathrm{~mL}$ ) were respectively diluted with deionised water to $1 \mathrm{~L}$ to prepare different extraction reagents. Moreover, the operating conditions including liquid (milliter)/solid (gram) (abbreviated as L/S) ratio, shaking frequency ( $\mathrm{r} / \mathrm{min}$ ), time (hour), and temperature were the same as method HJ/T300-2007.

Table 1. A comparison of HJ/T300-2007 and TCLP.

\begin{tabular}{|c|c|c|c|c|}
\hline Methods & $\begin{array}{c}\text { Preparation of } \\
\text { Extracting Reagent }\end{array}$ & $\begin{array}{c}\mathrm{pH} \\
\text { (Extracting Reagent) }\end{array}$ & $\mathrm{L} / \mathrm{S}$ & Shaking Conditions \\
\hline HJ/Т300-2007 & $\begin{array}{l}\text { Dilute } 17.25 \mathrm{~mL} \text { glacial } \\
\text { acetic acid with } \\
\text { deionised water to } 1 \mathrm{~L}\end{array}$ & 2. $64 \pm 0.05$ & $20: 1$ & $\begin{array}{c}\text { Rotary shaking } \\
\text { at } 30 \pm 2 \mathrm{r} / \min \text { for } 18 \pm 2 \mathrm{~h} \\
\text { at room temperature }\end{array}$ \\
\hline TCLP & $\begin{array}{l}\text { Dilute } 5.7 \mathrm{~mL} \text { glacial } \\
\text { acetic acid with } \\
\text { deionised water to } 1 \mathrm{~L}\end{array}$ & 2. $88 \pm 0.05$ & $20: 1$ & $\begin{array}{c}\text { Rotary shaking } \\
\text { at } 30 \pm 2 \mathrm{r} / \mathrm{min} \text { for } 18 \pm 2 \mathrm{~h} \\
\text { at room temperature }\end{array}$ \\
\hline
\end{tabular}


The $\mathrm{pH}$ value of leachate was measured using a $\mathrm{pH}$ meter (S470 SevenExcellence ${ }^{\mathrm{TM}}$, Mettler Toledo, Shanghai, China). The chemical composition of fly ash was analysed by X-ray fluorescence (XRF). The crystalline structure of the fly ash particles was identified by X-ray diffraction analysis (XRD, X'Pert PRO PANalytical B.V., Almelo, The Netherlands). The specific surface area was determined by an Autosorb-1-Csurface area analyser. The diameter of fly ash particles was analysed using a laser particle diameter analyser (LS-230 Coulter). Scanning electron microscopy (SEM) was used to observe the morphology of the fly ash particles before and after grinding.

\section{Results and Discussion}

\subsection{Characteristics of Milled and Washed fly Ash-Heavy Metals Leaching Tests}

The main cations, anions, and heavy metals of raw fly ash, MFA and WFA were analysed by XRF. Except for oxygen, calcium cations showed the highest concentration, followed by Si and $\mathrm{Al}$ (Table 2). As expected, the concentration of the four main heavy metals $(\mathrm{Zn}, \mathrm{Cu}, \mathrm{Pb}$ and $\mathrm{Cr}$ ) barely changed after $10 \mathrm{~h}$ of milling: MC treatment cannot eliminate heavy metals, but it might amend their speciation. Water washing dissolves soluble salts (mainly composed of $\mathrm{Cl}^{-}, \mathrm{Na}^{+}$and $\mathrm{K}^{+}$), with a weight loss of about $11 \%$.

Crystalline compounds were analysed by XRD. Figure 2 shows that water-soluble compounds $(\mathrm{NaCl}$ and $\mathrm{KCl})$ were efficiently removed during water washing, as evidenced by the disappearance of their XRD patterns in the washed fly ash (Figure 2b). The wave shapes of Figure 2a,c-e are quite similar, except for the decrease of some peak heights, indicating that no new visible crystals generated during mechanical treatment. Compared with raw fly ash (Figure 2a), the peak intensity of $\mathrm{NaCl}, \mathrm{KCl}$, $\mathrm{CaCO}_{3}$ and $\mathrm{CaSO}_{4}$ obviously weakened during the milling of fly ash, while that of $\mathrm{SiO}_{2}$ and $\mathrm{Fe}_{2} \mathrm{O}_{3}$ had visible expansions indicating the formation of some nanostructured materials (Figure 2c-e).

Table 2. The main cations, anions, and heavy metals in the fly ash.

\begin{tabular}{cccc}
\hline $\begin{array}{c}\text { Cations, Anions, } \\
\text { and Heavy Metals }\end{array}$ & Raw Fly Ash & $\begin{array}{c}\text { Milled Fly Ash } \\
(\mathbf{1 0} \text { h of Milling) }\end{array}$ & Washed Fly Ash \\
\hline $\mathrm{O}^{\mathrm{a}}$ & $34.71 \pm 0.3$ & $35.69 \pm 0.3$ & $37.97 \pm 0.3$ \\
$\mathrm{Ca}^{\mathrm{a}}$ & $16.98 \pm 0.15$ & $15.95 \pm 0.15$ & $17.88 \pm 0.15$ \\
$\mathrm{Si}^{\mathrm{a}}$ & $11.18 \pm 0.10$ & $13.26 \pm 0.11$ & $13.18 \pm 0.11$ \\
$\mathrm{Al}^{\mathrm{a}}$ & $5.80 \pm 0.08$ & $5.84 \pm 0.08$ & $6.39 \pm 0.09$ \\
$\mathrm{Cl}^{\mathrm{a}}$ & $7.43 \pm 0.13$ & $6.12 \pm 0.12$ & $1.37 \pm 0.06$ \\
$\mathrm{C}^{\mathrm{a}}$ & $7.50 \pm 0.13$ & $7.61 \pm 0.13$ & $7.96 \pm 0.13$ \\
$\mathrm{Mg}^{\mathrm{a}}$ & $3.41 \pm 0.07$ & $3.02 \pm 0.07$ & $3.92 \pm 0.07$ \\
$\mathrm{Fe}^{\mathrm{a}}$ & $2.86 \pm 0.07$ & $2.98 \pm 0.07$ & $3.48 \pm 0.08$ \\
$\mathrm{P}^{\mathrm{a}}$ & $1.46 \pm 0.04$ & $1.24 \pm 0.04$ & $1.87 \pm 0.04$ \\
$\mathrm{~S}^{\mathrm{a}}$ & $1.28 \pm 0.04$ & $1.06 \pm 0.04$ & $1.61 \pm 0.04$ \\
$\mathrm{Na}^{\mathrm{a}}$ & $4.44 \pm 0.09$ & $4.25 \pm 0.09$ & $1.91 \pm 0.06$ \\
$\mathrm{~K}^{\mathrm{a}}$ & $1.68 \pm 0.06$ & $1.67 \pm 0.06$ & $0.897 \pm 0.043$ \\
$\mathrm{Ti}^{\mathrm{a}}$ & $0.554 \pm 0.03$ & $0.55 \pm 0.03$ & $0.634 \pm 0.031$ \\
$\mathrm{Zn}^{\mathrm{b}}$ & $4160 \pm 210$ & $4110 \pm 210$ & $5060 \pm 250$ \\
$\mathrm{Cu}^{\mathrm{b}}$ & $996 \pm 50$ & $980 \pm 50$ & $1170 \pm 60$ \\
$\mathrm{Mn}^{\mathrm{b}}$ & $770 \pm 39$ & $780 \pm 39$ & $931 \pm 47$ \\
$\mathrm{~Pb}^{\mathrm{b}}$ & $677 \pm 34$ & $685 \pm 34$ & $815 \pm 41$ \\
$\mathrm{Cr}^{\mathrm{b}}$ & $408 \pm 20$ & $453 \pm 24$ & $484 \pm 24$ \\
$\mathrm{Ni}^{\mathrm{b}}$ & $77 \pm 4$ & $83 \pm 4$ & $94 \pm 5$ \\
$\mathrm{Cd}^{\mathrm{b}}$ & $26 \pm 6$ & $32 \pm 6$ & $20 \pm 9$ \\
\hline
\end{tabular}

Notes: ${ }^{a}$ Unit: $\%(\mathrm{w} / \mathrm{w}){ }^{\mathrm{b}}$ Unit: $\mathrm{mg} / \mathrm{kg}$.

Different sensitivity of these crystalline phases to ball milling is due to their hardness. The decrease in intensity is presumably due to partial amorphisation of phases, a typical effect induced by ball milling [12,26], and the extent of amorphisation kept enhancing with the increase of milling time. It is 
known that high energy ball mill can cause the transformation of crystalline material into amorphous state, increasing the amorphous content and enhancing its activity [14-17].

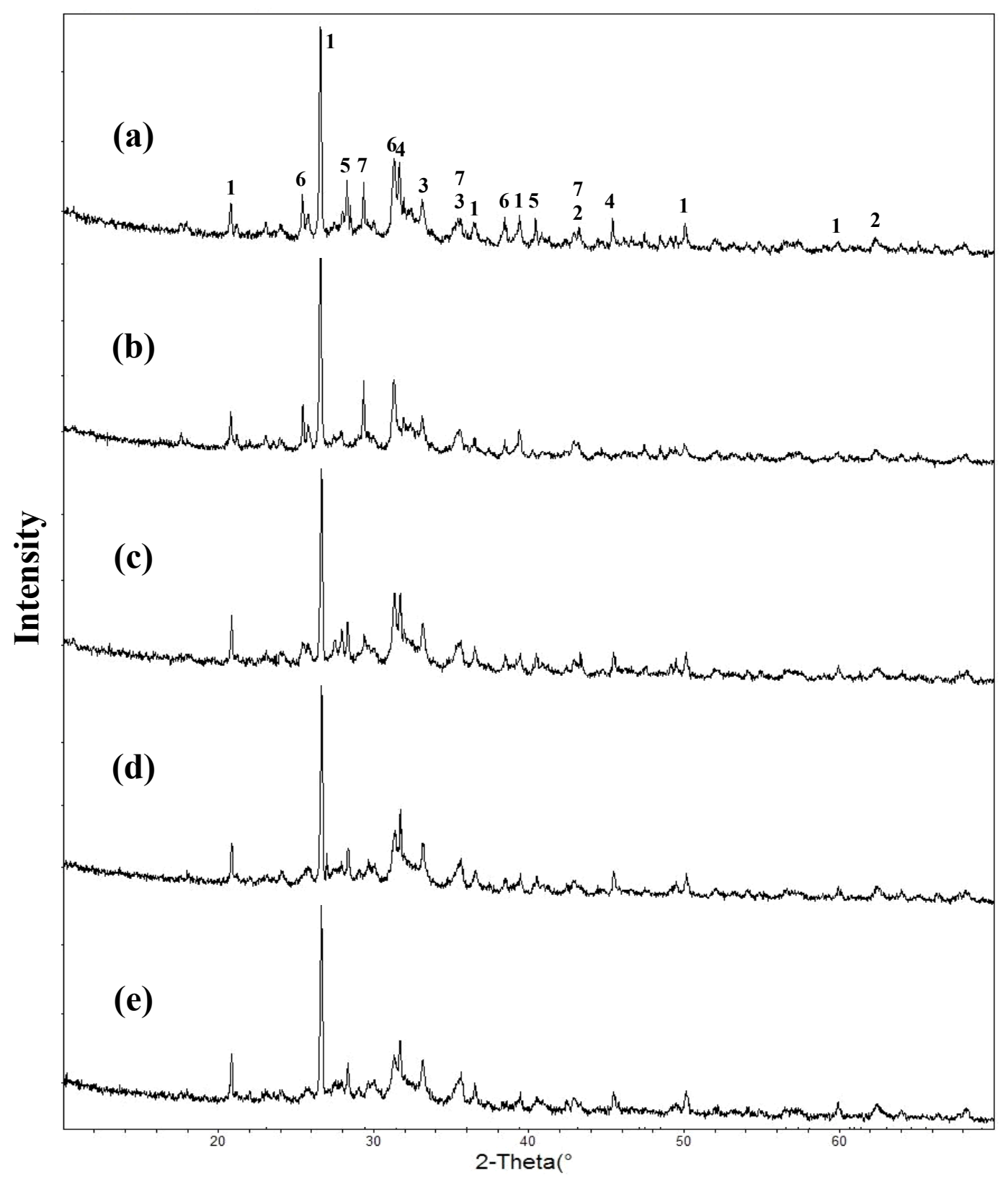

Figure 2. XRD patterns of (a) raw fly ash; (b) washed fly ash; (c-e) milled fly ash after (c) $1 \mathrm{~h}$; (d) 4 h; (e) 10 h of milling. 1: $\mathrm{SiO}_{2}, 2: \mathrm{MgO}, 3: \mathrm{Fe}_{2} \mathrm{O}_{3}, 4: \mathrm{NaCl}, 5: \mathrm{KCl}, 6: \mathrm{CaSO}_{4}, 7: \mathrm{CaCO}_{3}$.

Both MFA and MWFA were leached according to method HJ/T300-2007 (Table 1). The results of the leaching test on fly ash after $10 \mathrm{~h}$ of milling are shown in Table 3. For FA, the leaching concentration of $\mathrm{Cu}, \mathrm{Cr}$, and $\mathrm{Pb}$ decreases from $15.48 \mathrm{mg} / \mathrm{L}, 1.113 \mathrm{mg} / \mathrm{L}$, and $1.215 \mathrm{mg} / \mathrm{L}$ to $10.69 \mathrm{mg} / \mathrm{L}, 0.444 \mathrm{mg} / \mathrm{L}$, and $0.662 \mathrm{mg} / \mathrm{L}$ after $10 \mathrm{~h}$ of milling, respectively. For WFA, the leachate concentration decreases from $13.29 \mathrm{mg} / \mathrm{L}, 0.848 \mathrm{mg} / \mathrm{L}$, and $1.006 \mathrm{mg} / \mathrm{L}$ to $3.55 \mathrm{mg} / \mathrm{L}, 0.016 \mathrm{mg} / \mathrm{L}$, and $0.141 \mathrm{mg} / \mathrm{L}$ after $10 \mathrm{~h}$ of milling, respectively for $\mathrm{Cu}, \mathrm{Cr}$, and $\mathrm{Pb}$. MC treatment shows the strongest stabilization effect for $\mathrm{Cr}$, with $60.1 \%$ for FA and $98.1 \%$ for WFA, respectively. The values for $\mathrm{Cu}$ and $\mathrm{Pb}$ were $30.9 \%$ and $45.5 \%$ for FA, against $73.3 \%$ and $86.1 \%$ for WFA. After a period of milling the leaching of $\mathrm{Cu}, \mathrm{Cr}$, and $\mathrm{Pb}$ was efficiently suppressed; hence, washing out the soluble salts strongly promotes stabilization. 
However, for $\mathrm{Zn}, \mathrm{Cd}$, and Ni MC treatment has little effect on the stabilization. Particularly, the leaching concentration of $\mathrm{Ni}$ obviously increased after ball milling. In addition, the $\mathrm{pH}$ value of leachate kept rising as milling time increasing.

Table 3. Leaching test results after milling.

\begin{tabular}{ccccccccc}
\hline Heavy Metals & Milling Time & $\mathbf{C u}$ & $\mathbf{P b}$ & $\mathbf{C r}$ & $\mathbf{N i}$ & $\mathbf{C d}$ & $\mathbf{Z n}$ & $\mathbf{p H}$ \\
\hline \multirow{3}{*}{ FA } & $0 \mathrm{~h}^{\mathrm{a}}$ & 15.48 & 1.21 & 1.11 & 0.39 & 0.69 & 48.00 & 5.50 \\
& $2 \mathrm{~h}$ & 12.86 & 0.83 & 0.71 & 0.49 & 0.67 & 46.79 & 5.59 \\
& $6 \mathrm{~h}$ & 11.73 & 0.74 & 0.57 & 0.56 & 0.66 & 46.05 & 5.66 \\
\multirow{3}{*}{ WFA } & $10 \mathrm{~h}$ & 10.69 & 0.66 & 0.44 & 0.618 & 0.663 & 45.45 & 5.71 \\
& $0 \mathrm{~h}^{\mathrm{a}}$ & 13.29 & 1.006 & 0.85 & 0.356 & 0.705 & 47.40 & 5.69 \\
& $2 \mathrm{~h}$ & 7.01 & 0.53 & 0.30 & 0.58 & 0.65 & 43.15 & 6.00 \\
& $6 \mathrm{~h}$ & 5.21 & 0.31 & 0.14 & 0.71 & 0.62 & 40.96 & 6.11 \\
& $10 \mathrm{~h}$ & 3.55 & 0.14 & 0.016 & 0.80 & 0.59 & 39.11 & 6.29 \\
\hline
\end{tabular}

Notes: Unit: $\mathrm{mg} /$ L. $^{\text {a }}$ : Not milled.

\subsection{Variation in the Particle Size of Milled Fly Ash}

The mean particle size and the specific surface area (BET) both evolve as function of milling time (Figure 3). Before milling the average particle size of fly ash was $56.8 \mu \mathrm{m}$; it rapidly decreased to $7.8 \mu \mathrm{m}$ during the first hour of milling and then slightly reduced further reaching $4.3 \mu \mathrm{m}$ after $10 \mathrm{~h}$ of milling. Before milling the BET specific surface of fly ash only attained $1.2 \mathrm{~m}^{2} / \mathrm{g}$; yet it quickly augmented to $3.1 \mathrm{~m}^{2} / \mathrm{g}$ after $2 \mathrm{~h}$ of milling. After that, the BET of fly ash only slightly changed as milling goes on. Thus, the increase of BET surface accompanies the reduction of mean particle size.

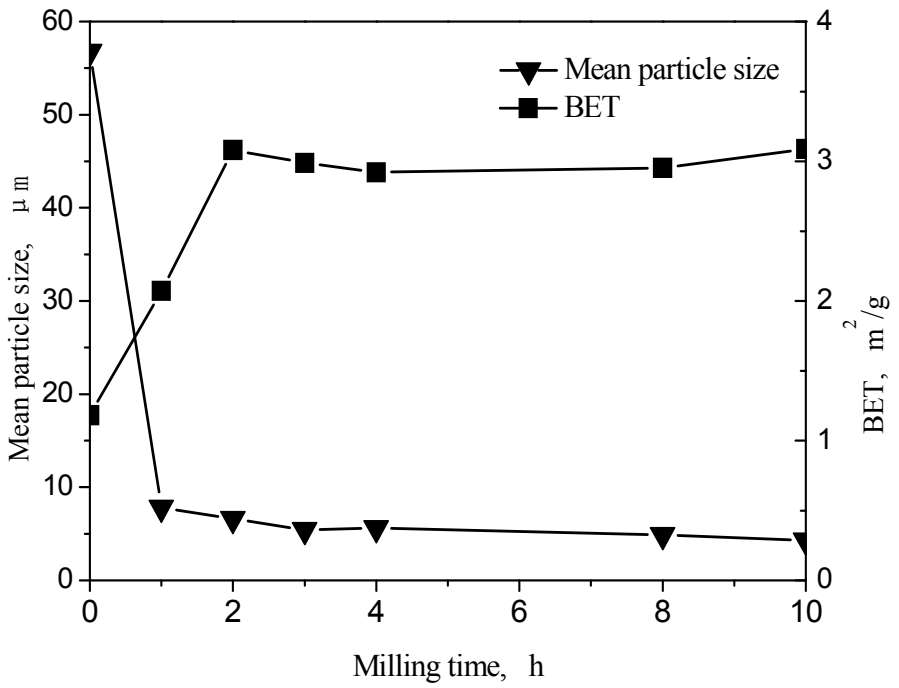

Figure 3. The evolution of the mean particle size and the BET specific surface vs. milling time.

The evolution of particle size distribution during milling is shown in Figure 4. Each distribution curve exhibits a poly-modal size distribution (Figure 4a). After only $1 \mathrm{~h}$ the initial curve obviously strongly shifts to the left (finer particles); later evolution becomes much slower. A peak with a mean size of ca. 1-2 $\mu \mathrm{m}$ emerges during grinding, and its peak height keeps slowly growing with rising milling time. The cumulative sketch in Figure $4 \mathrm{~b}$ demonstrates a shift towards small size classes for all milling time $(<10 \mathrm{~h})$, indicating that the fragmentation of particles play a main role compared with agglomeration during milling process. 


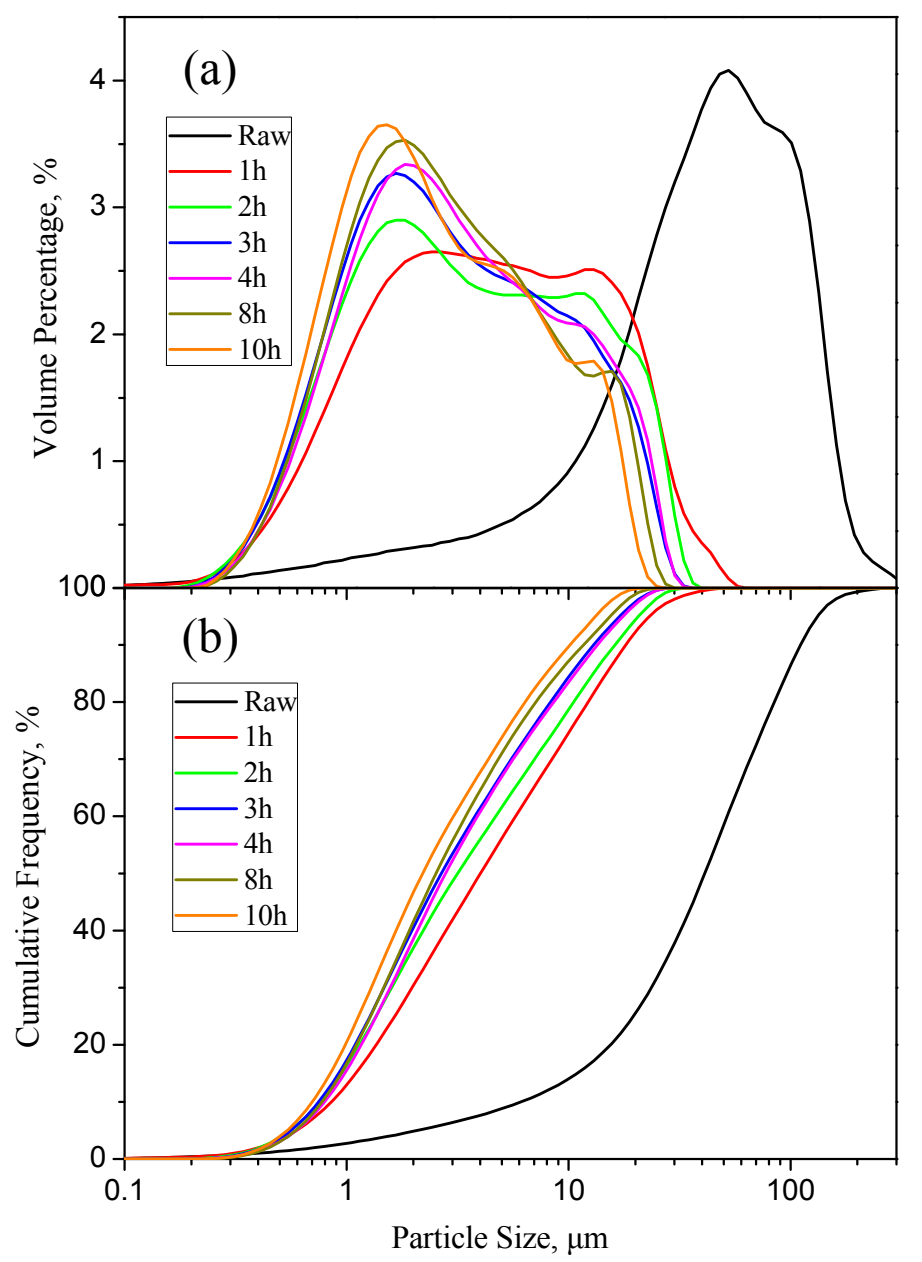

Figure 4. Evolution in the particle size distribution during milling: (a) 0-3 h; (b) 3-10 h.

The surface of particles was observed by SEM. Figure $5 \mathrm{a}$,b shows the raw fly ash before milling: it consists of many large particles. After $2 \mathrm{~h}$ of milling these were reduced to smaller sizes (Figure $5 c, d$ ), further milling (Figure 5e,f) kept bringing changes in size, which coincided with the evolution of particle size.

For the heavy metals stabilization in soil, Montinaro et al. [20] found that $\mathrm{Pb}, \mathrm{Cd}$ and $\mathrm{Zn}$ complexes diffuse within the solid matrix following the accumulation of crystalline defects. Therefore, the heavy metals are irreversibly adsorbed into crystalline reticulum to prevent their leaching. However, in the present work, MC treatment has no effect on stabilization for $\mathrm{Cd}, \mathrm{Zn}$, and Ni. The elements Ni, $\mathrm{Cu}$, and $\mathrm{Zn}$ have the adjacent position in the periodic table of elements, and they also have similar chemical characteristics such as electrovalence and ionic radius. If $\mathrm{Cu}$ can be solidified by irreversible chemical adsorption, $\mathrm{Ni}$ and $\mathrm{Zn}$ are supposed to give similar results (contradicting the results in Table 3). Therefore, this kind of mechanism is not suitable for the explanation of the stabilization of $\mathrm{Cu}$, $\mathrm{Cr}$, and $\mathrm{Pb}$ in MSWI fly ash.

$\mathrm{Li}$ et al. [23] reported that- to achieve stabilization- $\mathrm{Pb}$ in fly ash was sealed into the milled fly ash during wet milling. Nevertheless, the size of fly ash decreased significantly after milling as in Figures 3-5, and the BET of fly ash increased as in Figure 3. These phenomena are in conflict with the sealing of heavy metals. Besides, such purely physical inclusion should bring the same effect to all heavy metals, including $\mathrm{Cd}, \mathrm{Zn}$ and $\mathrm{Ni}$. In another word, also $\mathrm{Cd}, \mathrm{Zn}$ and Ni ought to be solidified, which conflicts with the results in Table 3. Consequently, the stabilization mechanism in the present work (dry milling) mightn't be the sealing of heavy metals. 

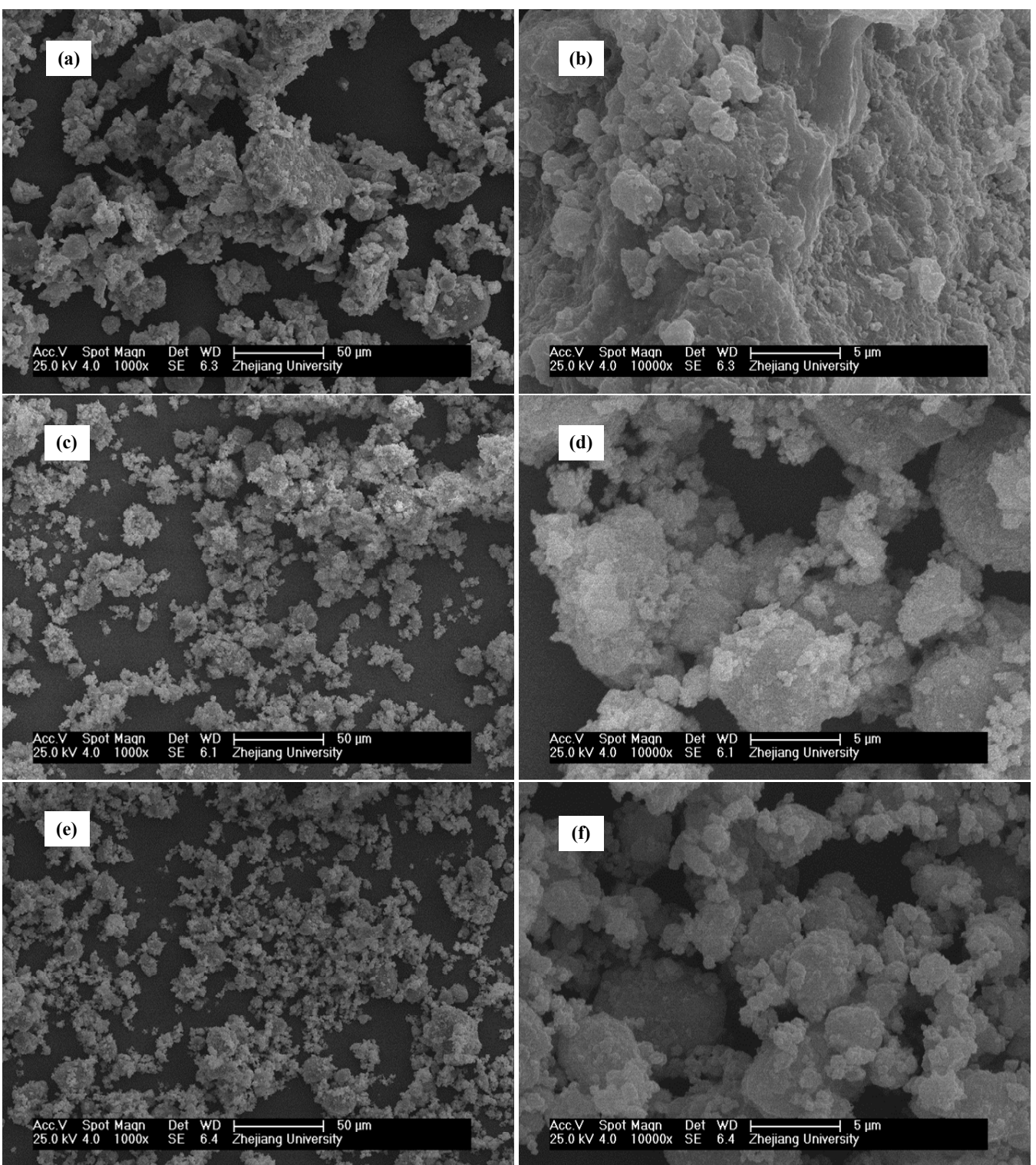

Figure 5. SEM micrographs for (a) raw fly ash magnified at $\times 1000$ (1k); (b) raw fly ash at $\times 10 \mathrm{k}$; (c) $2 \mathrm{~h}$ MFA at $\times 1 \mathrm{k}$; (d) $2 \mathrm{~h}$ MFA at $\times 10 \mathrm{k}$; (e) $10 \mathrm{~h}$ MFA at $\times 1 \mathrm{k}$; (f) $10 \mathrm{~h}$ MFA at $\times 10 \mathrm{k}$.

The MC treatment of powdered particles comprehends repeated flattening, cold-welding, fracturing and re-welding [12]. As a result, the particle size greatly decreased, accompanying with rising BET (Figure 3). Particles are repeatedly fragmented and again aggregated, forming many fresh surfaces and significantly increasing surface energy, accumulating crystalline deformation and vacancies and leading to amorphisation of crystals $[16,27]$ as shown in Figure 2. Thus, the particles are activated by high energy ball milling, which is defined as mechanical activation, and the diffusivity of various compounds is largely enhanced $[12,28]$. It is known that the dissolution rate of organic and inorganic materials can be enhanced by mechanical activation [29-36]. Fly ash contains metallic oxides, such as $\mathrm{CaO}, \mathrm{MgO}, \mathrm{Fe}_{2} \mathrm{O}_{3}, \mathrm{Al}_{2} \mathrm{O}_{3}$, and carbonates $\mathrm{CaCO}_{3}$ etc. (Table 2 and Figure 2), exerting strong acid buffering activity. With the activation of fly ash particles, the solubility of these basic compounds will increase, resulting in a rising $\mathrm{pH}$ value of leachate (Table 3). Washing pretreatment removed lots of soluble salts, which had no effect on acid buffering. Therefore, the washed fly ash showed a slight rise in the $\mathrm{pH}$ value of leachate, compared with raw fly ash. 


\subsection{Leaching Test Results Related to $\mathrm{pH}$ and the Assessment of Stabilization}

Different acetic acid buffer solutions were prepared to operate a leaching test for raw fly ash, with the aim to obtaining information on the influence of the $\mathrm{pH}$ value of leachate on the concentration of the heavy metals leached. The test results were shown in Table 4, and Figure 6 was also made based on it. Figure 6 reveals that this concentration augmented as the $\mathrm{pH}$ value of leachate diminishes, within a $\mathrm{pH}$ range of 4.5-11. This is a typical leaching property of heavy metals of MSWI fly ash. Especially, in a $\mathrm{pH}$ range of 5.5-6.5 (Figure 7), the leaching concentration of $\mathrm{Cu}, \mathrm{Cr}$, and $\mathrm{Pb}$ changed significantly, while that of $\mathrm{Cd}, \mathrm{Zn}$, and $\mathrm{Ni}$ varied little.

Table 4. Leaching concentration of heavy metals related to $\mathrm{pH}$.

\begin{tabular}{ccccccc}
\hline $\mathbf{p H}$ & $\mathbf{C r}$ & $\mathbf{P b}$ & $\mathbf{C d}$ & $\mathbf{N i}$ & $\mathbf{C u}$ & $\mathbf{Z n}$ \\
\hline 10.98 & 0.044 & 0.0069 & ND & ND & 0.016 & 0.075 \\
10.76 & 0.26 & 0.0052 & ND & ND & 0.037 & 0.010 \\
10.57 & 0.50 & 0.0031 & ND & ND & 0.050 & 0.0045 \\
9.63 & 1.06 & 0.0020 & ND & 0.0003 & 0.077 & 0.0009 \\
8.30 & 1.36 & 0.0019 & 0.015 & 0.031 & 0.10 & 0.0087 \\
7.49 & 1.25 & 0.05 & 0.45 & 0.16 & 0.93 & 20.16 \\
6.92 & 0.009 & 0.11 & 0.46 & 0.22 & 1.98 & 36.20 \\
6.75 & 0.013 & 0.18 & 0.52 & 0.27 & 3.49 & 45.98 \\
6.16 & 0.079 & 0.39 & 0.54 & 0.31 & 6.59 & 54.67 \\
5.74 & 0.26 & 0.70 & 0.60 & 0.40 & 9.54 & 61.44 \\
5.42 & 0.75 & 1.08 & 0.66 & 0.41 & 12.31 & 63.18 \\
4.91 & 1.82 & 2.86 & 0.75 & 0.56 & 11.92 & 68.56 \\
4.69 & 2.31 & 4.40 & 0.76 & 0.62 & 15.52 & 72.96 \\
4.47 & 2.61 & 5.75 & 0.77 & 0.63 & 18.69 & 74.26 \\
\hline
\end{tabular}

Notes: Unit: $\mathrm{mg} / \mathrm{L} ; \mathrm{ND}$ : The concentration was lower than the detection limit of the ICP $(<0.0001 \mathrm{mg} / \mathrm{L})$.
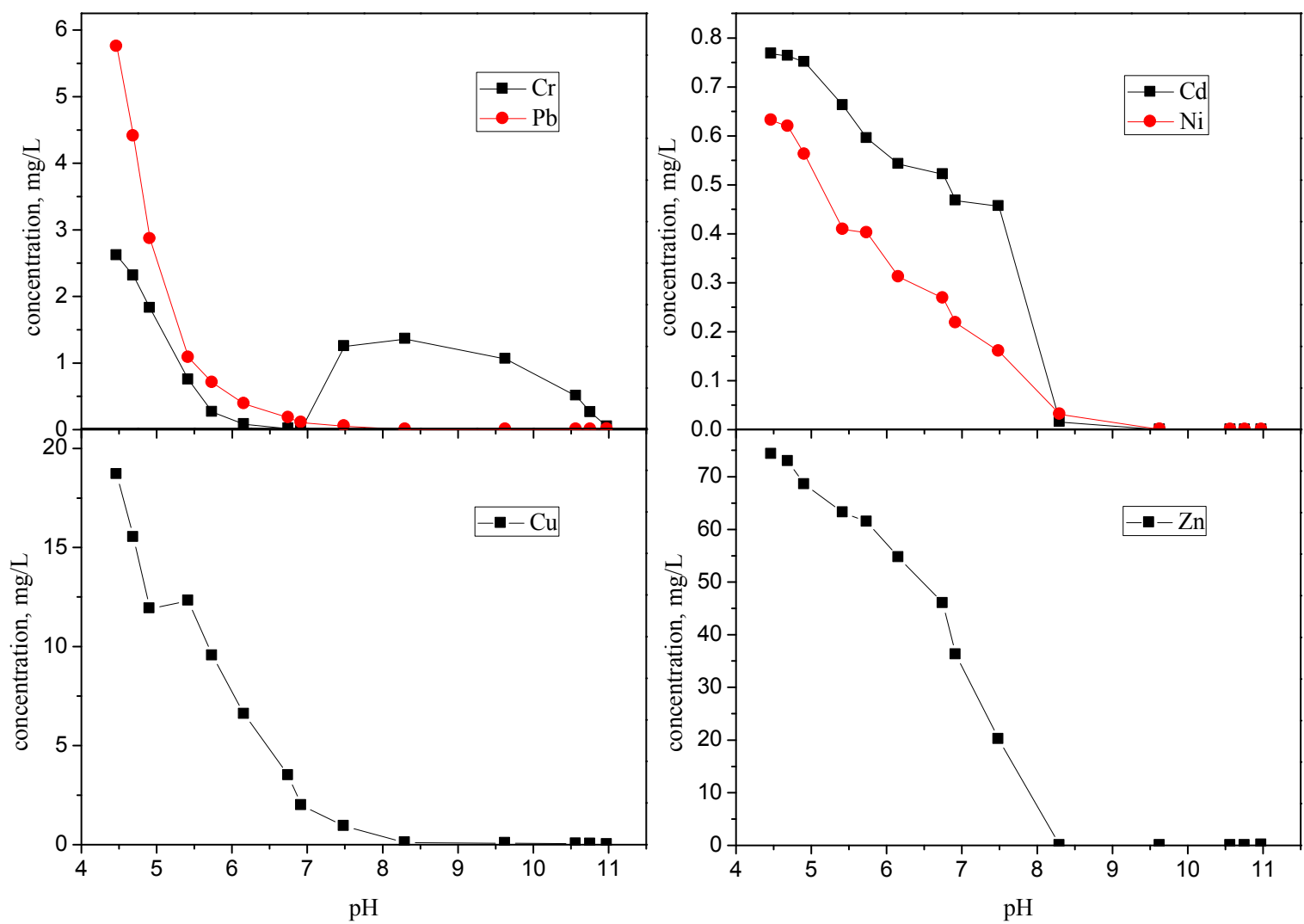

Figure 6. Evolution of leaching concentration of heavy metals vs. $\mathrm{pH}$ for raw fly ash. 

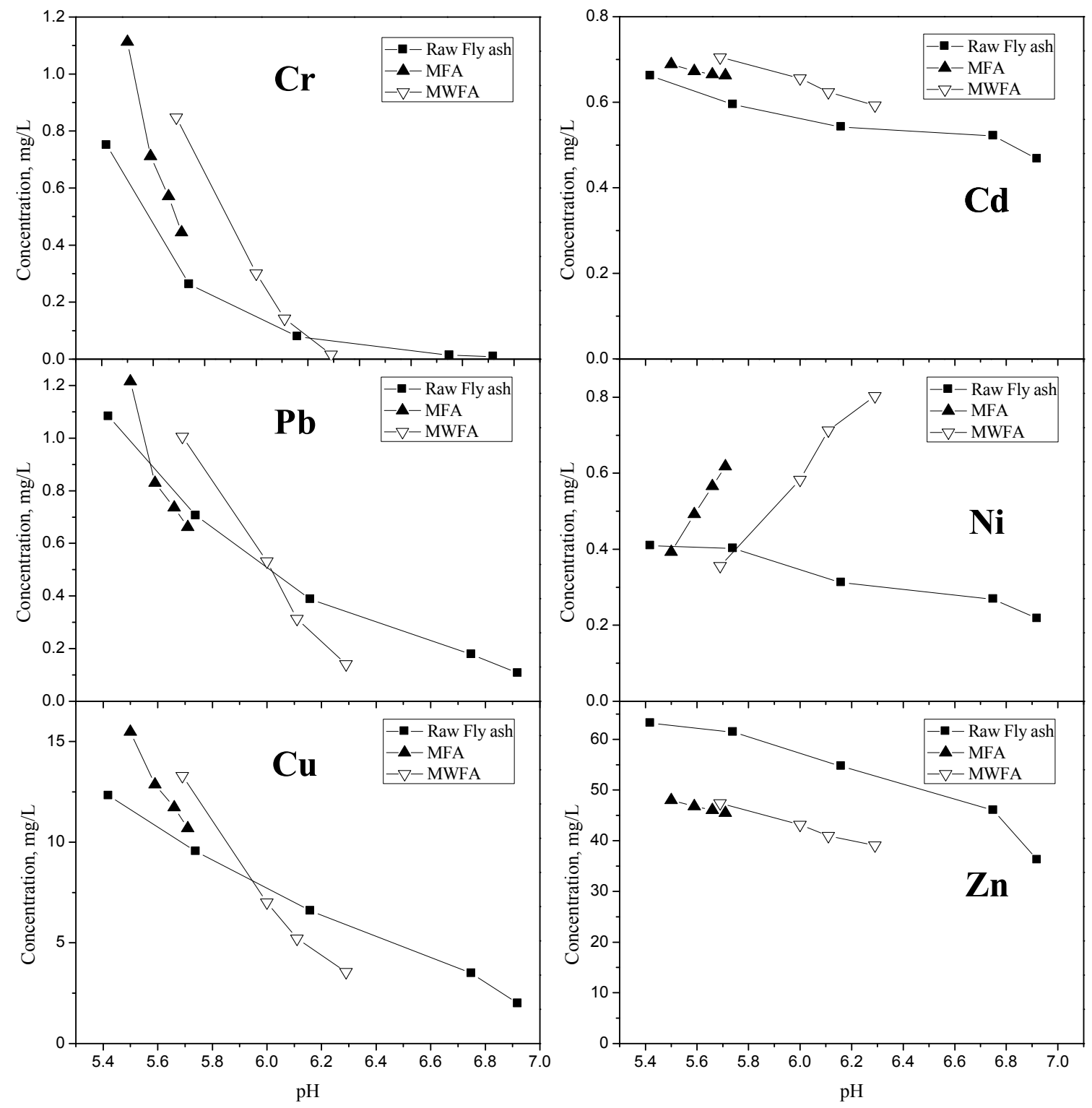

Figure 7. Evolution of leaching concentration vs. $\mathrm{pH}$ for raw fly ash, MFA, and MWFA.

As for MFA and MWFA, the $\mathrm{pH}$ value of leachate respectively increased from 5.5 and 5.69 to 5.71 and 6.29 after milling (Table 3). Correspondingly, their leaching concentration kept decreasing as $\mathrm{pH}$ rising. The evolution of leaching concentration versus $\mathrm{pH}$ value for raw fly ash, MFA, and MWFA were demonstrated in Figure 7. For all heavy metals except for Ni, their curves had almost the similar declining tendency, and the value of concentration was close. Therefore, after MC treatment, the concentration of $\mathrm{Cu}, \mathrm{Cr}$, and $\mathrm{Pb}$ in leachate lessened greatly, while that of $\mathrm{Cd}$ and $\mathrm{Zn}$ showed less loss, explaining why $\mathrm{MC}$ treatment was more effective for $\mathrm{Cu}, \mathrm{Cr}$, and $\mathrm{Pb}$ than for $\mathrm{Cd}$ and $\mathrm{Zn}$. The leaching concentration of $\mathrm{Ni}$ increased largely, because the activation of particles caused by milling might be the main factor in controlling the leaching of $\mathrm{Ni}$ compared with the change of $\mathrm{pH}$. In conclusion, $\mathrm{MC}$ treatment will activate fly ash particles and escalate the solubility of basic crystals therein: as a result, the $\mathrm{pH}$ value of leachate rises, resulting in reducing leachate concentration of some heavy metals, which are sensitive to the change of $\mathrm{pH}(\mathrm{Cu}, \mathrm{Cr}$, and $\mathrm{Pb})$. Moreover, washing pretreatment gave a higher ratio of acid buffer materials in fly ash, and the MWFA was supposed to have more variation of $\mathrm{pH}$ of its leachate, presenting in the promotion of stabilization efficiency. 
A sequential extraction test has been used to assess the MC treatment applied for heavy metals stabilization in fly ash. The fly ashes were successively extracted three times with the same extracting reagent used in method $\mathrm{HJ} / \mathrm{T} 300-2007$, and the operating conditions (L/S, shaking frequency, time, and temperature) were the same as in Table 1.

The results are shown in Table 5: the reducing of leaching concentration of heavy metals was only effective at the first leaching step, mainly caused by the rise of $\mathrm{pH}$. The leachate concentration of heavy metals in milled fly ash was even higher than that in raw fly ash at the second and third step, because acid buffer materials had been largely consumed at the first step. The sum of three times leaching concentration increased after milling for all elements in Table 5 except for $\mathrm{Pb}$, indicating that MC treatment indeed helped enhancing dissolution as the conclusion in 3.2. Particularly, the leaching concentration of $\mathrm{Pb}$ decreased after milling at all steps, indicating that $\mathrm{MC}$ treatment had a real stabilization effect to $\mathrm{Pb}$. The solubility of sulphate especially for $\mathrm{CaSO}_{4}$ in fly ash increased after milling, because the crystal of $\mathrm{CaSO}_{4}$ had obvious amorphisation during milling as in Figure 2 . Thereafter, $\mathrm{Pb}$ could combine with $\mathrm{SO}_{4}{ }^{2-}$ to form $\mathrm{PbSO}_{4}$, which is an insoluble compound both in water and acid, reducing the leaching of $\mathrm{Pb}$ in leachate.

Table 5. Sequential extraction test results.

\begin{tabular}{ccccccccccc}
\hline Heavy Metals & Steps & $\mathbf{C u}$ & $\mathbf{C r}$ & $\mathbf{P b}$ & $\mathbf{C d}$ & $\mathbf{N i}$ & $\mathbf{Z n}$ & $\mathbf{A l}$ & $\mathbf{F e}$ & $\mathbf{M n}$ \\
\hline \multirow{4}{*}{ FA } & 1st & 15.48 & 1.11 & 1.21 & 0.69 & 0.39 & 48.00 & 17.61 & 5.34 & 5.21 \\
& 2nd & 5.48 & 1.17 & 1.61 & 0.096 & 0.28 & 22.92 & 292.90 & 57.19 & 3.55 \\
& 3rd & 1.82 & 0.34 & 0.52 & 0.019 & 0.096 & 4.03 & 127.30 & 10.63 & 1.18 \\
& Sum & 22.79 & 2.62 & 3.34 & 0.80 & 0.77 & 74.95 & 437.81 & 73.17 & 9.95 \\
\hline \multirow{4}{*}{ MFA $^{\text {a }}$} & 1st & 10.69 & 0.44 & 0.66 & 0.66 & 0.62 & 45.45 & 23.27 & 6.35 & 7.38 \\
& 2nd & 8.14 & 1.81 & 1.32 & 0.11 & 0.23 & 28.62 & 343.90 & 71.59 & 3.53 \\
& 3rd & 2.83 & 0.58 & 0.41 & 0.023 & 0.047 & 4.91 & 159.80 & 33.23 & 1.18 \\
& Sum & 21.67 & 2.83 & 2.40 & 0.80 & 0.90 & 74.07 & 526.97 & 111.17 & 12.09 \\
\hline \multirow{3}{*}{ WFA } & 1st & 13.29 & 0.85 & 1.006 & 0.70 & 0.35 & 47.40 & 35.06 & 4.15 & 4.76 \\
& 2nd & 7.78 & 1.35 & 2.49 & 0.15 & 0.30 & 29.87 & 318.90 & 57.55 & 4.57 \\
& 3rd & 2.25 & 0.39 & 0.80 & 0.030 & 0.11 & 7.48 & 150.10 & 14.33 & 1.36 \\
& Sum & 23.32 & 2.60 & 4.30 & 0.89 & 0.77 & 84.75 & 504.06 & 76.03 & 10.70 \\
\hline \multirow{2}{*}{ WMFA $^{\text {a }}$} & 1st & 3.55 & 0.016 & 0.14 & 0.59 & 0.80 & 39.11 & 2.19 & 0.12 & 9.15 \\
& 2nd & 17.58 & 2.59 & 1.71 & 0.39 & 0.33 & 48.27 & 387.40 & 57.47 & 5.65 \\
& 3rd & 4.95 & 0.97 & 0.48 & 0.056 & 0.077 & 9.26 & 204.60 & 25.68 & 1.90 \\
& Sum & 26.09 & 3.58 & 2.33 & 1.03 & 1.21 & 96.64 & 594.18 & 83.27 & 16.71 \\
\hline
\end{tabular}

\section{Conclusions}

$\mathrm{MC}$ treatment reduces the leaching concentration of $\mathrm{Cu}, \mathrm{Cr}$, and $\mathrm{Pb}$, and a preliminary water washing pretreatment effectively promotes the efficiency of stabilization by removing the soluble salts. Fly ash particles can be activated through high energy ball milling, resulting in a significant decrease of particle size, an increase of its BET-surface, and the amorphisation of basic crystals. The dissolution rate of acid buffering oxides and carbonates from activated particles is enhanced, resulting in a rising $\mathrm{pH}$ value of the leachate, reducing the leaching concentration of some heavy metals which are sensitive to the variation of $\mathrm{pH}$ value. The stabilization of $\mathrm{Cu}$ and $\mathrm{Cr}$ is more like slowing down their release, because more leaching concentration of them was observed at the second and third extraction step. However, the leaching concentration of $\mathrm{Pb}$ may truly be reduced through the formation of insoluble sulphate. This could be an illuminating direction for the real stabilization of other heavy metals in fly ash in future research.

Acknowledgments: This Project was Supported by the Fundamental Research Funds for the Central Universities (No. 2016FZA4010, No. 2016XZZX002-02). 
Author Contributions: Shengyong Lu and Jianhua Yan gave the idea and guidance of this research. Zhiliang Chen did all the experiments and analysis and wrote this paper with the assist of Qiongjing Mao, Wei Chang, and $\mathrm{Xu}$ Wang. Alfons Buekens gave the English revision and writing instructions of this paper.

Conflicts of Interest: The authors declare no conflict of interest.

\section{References}

1. Zhang, Q.W.; Matsumoto, H.; Saito, F.; Baron, M. Debromination of hexabromobenzene by its co-grinding with CaO. Chemosphere 2002, 48, 787-793. [CrossRef]

2. Lu, S.; Huang, J.; Peng, Z.; Lia, X.; Yan, J. Ball milling 2,4,6-trichlorophenol with calcium oxide: Dechlorination experiment and mechanism considerations. Chem. Eng. J. 2012, 195, 62-68. [CrossRef]

3. Wei, Y.; Yan, J.; Lu, S.; Li, X. Mechanochemical decomposition of pentachlorophenol by ball milling. J. Environ. Sci. 2009, 21, 1761-1768. [CrossRef]

4. Zhang, K.; Huang, J.; Yu, G.; Zhang, Q.; Deng, S.; Wang, B. Destruction of Perfluorooctane Sulfonate (PFOS) and Perfluorooctanoic Acid (PFOA) by Ball Milling. Environ. Sci. Technol. 2013, 47, 6471-6477. [CrossRef] [PubMed]

5. Monagheddu, M.; Mulas, G.; Doppiu, S.; Cocco, G.; Raccanelli, S. Reduction of polychlorinated dibenzodioxins and dibenzofurans in contaminated muds by mechanically induced combustion reactions. Environ. Sci. Technol. 1999, 33, 2485-2488. [CrossRef]

6. Nah, I.W.; Hwang, K.; Shul, Y. Effect of metal and glycol on mechanochemical dechlorination of polychlorinated biphenyls (PCBs). Chemosphere 2008, 73, 138-141. [CrossRef] [PubMed]

7. Shu, S.; Junya, K.; Fumio, S.; Shimme, K.; Masuda, S.; Inoue, T. Effect of additives on dechlorination of PVC by mechanochemical treatment. J. Mater. Cycles Waste Manag. 2001, 1, 20-23.

8. Mao, Q.; Peng, Z.; Lu, S.; Yan, J. Mechanochemical Degradation of OCDD/OCDF in Fly Ash from Medical Waste Incinerators. Acta Chim. Sin. 2012, 70, 659-666. [CrossRef]

9. Peng, Z.; Ding, Q.; Sun, Y.; Jiang, C.; Gao, X.; Yan, J. Characterization of mechanochemical treated fly ash from a medical waste incinerator. J. Environ. Sci. 2010, 22, 1643-1648. [CrossRef]

10. Mitoma, Y.; Miyata, H.; Egashira, N.; Simion, A.M.; Kakeda, M.; Simion, C. Mechanochemical degradation of chlorinated contaminants in fly ash with a calcium-based degradation reagent. Chemosphere 2011, 83, 1326-1330. [CrossRef] [PubMed]

11. Yan, J.H.; Peng, Z.; Lu, S.Y.; Li, X.D.; Ni, M.J.; Cen, K.F.; Dai, H.F. Degradation of PCDD/Fs by mechanochemical treatment of fly ash from medical waste incineration. J. Hazard. Mater. 2007, 147, $652-657$. [CrossRef] [PubMed]

12. Suryanarayana, C. Mechanical alloying and milling. Progress Mater. Sci. 2001, 46, 1-184. [CrossRef]

13. El-Eskandarany, M.S.; El-Bahnasawy, H.N.; Ahmed, H.A.; Eissa, N.A. Mechanical solid-state reduction of haematite with magnesium. J. Alloys Compd. 2001, 314, 286-295. [CrossRef]

14. Marjanovic, N.; Komljenovic, M.; Bascarevic, Z.; Nikolić, V. Improving reactivity of fly ash and properties of ensuing geopolymers through mechanical activation. Constr. Build. Mater. 2014, 57, 151-162. [CrossRef]

15. Kumar, S.; Kumar, R. Mechanical activation of fly ash: Effect on reaction, structure and properties of resulting geopolymer. Ceramics Int. 2011, 37, 533-541. [CrossRef]

16. Juhász, A.Z.; Oppczky, L. Mechanical Activation of Minerals by Grinding: Pulverising and Morphology of Particles; AkadémiaiKiadó: Budapest, Hungary, 1990.

17. Hamzaoui, R.; Bouchenafa, O.; Guessasma, S.; Leklouc, N.; Bouaziz, A. The sequel of modified fly ashes using high energy ball milling on mechanical performance of substituted past cement. Mater. Des. 2016, 90, 29-37. [CrossRef]

18. El-Eskandarany, M.S.; Matsushita, M.; Inoue, A. Phase transformations of ball-milled Nb50Zr10A110Ni10Cu20 powders and the effect of annealing. J. Alloys Compd. 2001, 329, $239-252$. [CrossRef]

19. Hamzaoui, R.; Muslim, F.; Guessasma, S.; Bennabia, A.; Guillin, J. Structural and thermal behavior of proclay kaolinite using high energy ball milling process. Powder Technol. 2015, 271, 228-237. [CrossRef]

20. Montinaro, S.; Concas, A.; Pisu, M.; Cao, G. Immobilization of heavy metals in contaminated soils through ball milling with and without additives. Chem. Eng. J. 2008, 142, 271-284. [CrossRef] 
21. Nomura, Y.; Fujiwara, K.; Terada, A.; Nakai, S.; Hosomi, M. Prevention of lead leaching from fly ashes by mechanochemical treatment. Waste Manag. 2010, 30, 1290-1295. [CrossRef] [PubMed]

22. Nomura, Y.; Okada, T.; Nakai, S.; Hosomi, M. Inhibition of heavy metal elution from fly ashes by mechanochemical treatment and cementation. Kagaku Kogaku Ronbunshu 2006, 32, 196-199. [CrossRef]

23. Li, M.; Sun, C.; Gau, S.; Chuang, C.J. Effects of wet ball milling on lead stabilization and particle size variation in municipal solid waste incinerator fly ash. J. Hazard. Mater. 2010, 174, 586-591. [CrossRef] [PubMed]

24. Sun, C.; Li, M.; Gau, S.; Chuang, C.J. Effect of the milling solution on lead stabilization in municipal solid waste incinerator fly ash during the milling processes. Waste Manag. 2011, 31, 318-324. [CrossRef] [PubMed]

25. Nomura, Y.F.K.T. Detoxification of fly ash by mechanochemical treatment with blast furnace slag and the usability of the residues as cement materials. J. Jpn. Soc. Waste Manag. Experts 2006, 5, 355-360. [CrossRef]

26. Suryanarayana, C. Bibliography on Mechanical Alloying and Milling; Cambridge International Science Publishing: Cambridge, UK, 1995.

27. Orumwense, O.A.; Forssberg, E. Surface and structural-changes in wet ground minerals. Powder Technol. 1991, 68, 23-29. [CrossRef]

28. Lu, L.; Lai, M.O.; Zhang, S. Diffusion in mechanical alloying. J. Mater. Proc. Technol. 1997, 67, $100-104$. [CrossRef]

29. Alleso, M.; Chieng, N.; Rehder, S.; Rantanen, J.; Rades, T.; Aaltonen, J. Enhanced dissolution rate and synchronized release of drugs in binary systems through formulation: Amorphous naproxen-cimetidine mixtures prepared by mechanical activation. J. Control. Release 2009, 136, 45-53. [CrossRef] [PubMed]

30. Colombo, I.; Grassi, G.; Grassi, M. Drug Mechanochemical Activation. J. Pharm. Sci. 2009, 98, 3961-3986. [CrossRef] [PubMed]

31. Elamin, A.A.; Ahlneck, C.; Alderborn, G.; Nyström, C. Increased metastable solubility of milled griseofulvin, depending on the formation of a disordered surface-structure. Int. J. Pharm. 1994, 111, 159-170. [CrossRef]

32. Gbureck, U.; Grolms, O.; Barralet, J.E.; Grover, L.M.; Thull, R. Mechanical activation and cement formation of beta-tricalcium phosphate. Biomaterials 2003, 24, 4123-4131. [CrossRef]

33. Huang, Z.; Lu, J.; Li, X.; Tong, Z. Effect of mechanical activation on physico-chemical properties and structure of cassava starch. Carbohydr. Polym. 2007, 68, 128-135. [CrossRef]

34. Huang, Z.; Xie, X.; Chen, Y.; Lu, J.; Tong, Z. Ball-milling treatment effect on physicochemical properties and features for cassava and maize starches. Comptes Rendus Chim. 2008, 11, 73-79. [CrossRef]

35. Murty, B.S.; Ranganathan, S. Novel materials synthesis by mechanical alloying/milling. Int. Mater. Rev. 1998, 43, 101-141. [CrossRef]

36. Sakai, S.; Yamada, Y.; Zenke, T.; Kawakamia, K. Novel chitosan derivative soluble at neutral pH and in-situ gellable via peroxidase-catalyzed enzymatic reaction. J. Mater. Chem. 2009, 19, 230-235. [CrossRef]

(C) 2016 by the authors; licensee MDPI, Basel, Switzerland. This article is an open access article distributed under the terms and conditions of the Creative Commons Attribution (CC-BY) license (http://creativecommons.org/licenses/by/4.0/). 